doi" http://dx.doi.org/10.15448/1980-6523.2018.1.29259

\title{
Human pulp pesponse to Portland cement and MTA
}

Antônio Vinicius Holanda Barbosa ${ }^{\mathrm{a}}$, Valdeci Elias dos Santos Junior ${ }^{\mathrm{b}}$, Márcia Marques Martins ${ }^{\mathrm{c}}$, Leila Soares Ferreira ${ }^{\mathrm{d}}$, Ana Paula Veras Sobral ${ }^{\mathrm{e}}$

\section{ABSTRACT}

OBJECTIVE: To investigate the pulpal response to direct pulp capping in healthy human teeth with Portland cement (PC) as against mineral trioxide aggregate (MTA) as control. METHODS: Forty healthy human third molars indicated for extraction were randomly divided into two groups: PC and MTA. The teeth had iatrogenic pulp exposed and direct pulp capping with PC or MTA. After 1, 7, 14 and 21 days, the teeth were extracted and prepared for histological examination and bacterial detection. The Mann-Whitney test was applied for statistical analysis $(p<0.05)$.

RESULTS: The MTA presented higher capacity to form of dentin bridges at 14- and 21-day intervals $(p<0.05)$. However, no significant statistical difference was found between the groups at all evaluated intervals $(p>0.05)$ for the response variables of inflammatory cells, soft tissue organization and bacterial staining.

CONCLUSION: The PC has a biocompatibility equivalent to the MTA but with a lower capacity to form of dentin bridges. Therefore, MTA should be the material of choice for direct pulp capping

Keywords: biocompatibility; human pulp; mineral trioxide aggregate; portland cement; pulp capping.

\section{Resposta da polpa humana ao cemento Portland e ao MTA RESUMO}

OBJETIVO: Investigar a resposta pulpar ao capeamento pulpar direto em dentes humanos saudáveis com cimento Portland (PC) em relação ao agregado de trióxido mineral (MTA), como controle.

METODOLOGIA: Foram utilizados 40 molares humanos sadios indicados para extração, aleatoriamente divididos em dois grupos: PC e MTA. Os dentes tiveram a polpa exposta iatrogenicamente e em seguida foi realizado o capeamento pulpar direto com PC ou MTA. Após 1, 7, 14 e 21 dias, os dentes foram extraídos e preparados para exame histológico e detecção bacteriana. O teste de Mann-Whitney foi aplicado para análise estatística $(\mathrm{p}<0,05)$.

RESULTADOS: O MTA apresentou maior capacidade de formação de pontes dentinárias nos intervalos de $14 \mathrm{e}$ 21 dias $(p<0,05)$. No entanto, não foi encontrada diferença estatística significativa entre os grupos em todos os intervalos avaliados $(p>0,05)$ para as variáveis de resposta de células inflamatórias, organização de tecidos moles e coloração bacteriana.

CONCLUSÃO: O PC tem uma biocompatibilidade equivalente ao MTA, mas com menor capacidade de formar pontes dentinárias. Portanto, o MTA deve ser o material de escolha para o capeamento direto da polpa

Palavras-chave: biocompatibilidade; polpa humana; agregado de trióxido mineral; cimento portland; capeamento pulpar. a Department of endodontics, School of Dentistry, FACIPE - Faculty Integrated of Pernambuco, Recife, Brazil

${ }^{b}$ Department of Pediatric dentistry, School of Dentistry, Federal University of Alagoas, Maceió, Brazil

${ }^{c}$ Department of Restorative Dentistry, School of Dentistry, University of São Paulo (USP), São Paulo, Brazil

d Department of Restorative Dentistry, University of Ibirapuera. São Paulo, Brazil

e Department of Oral Pathology, School of Dentistry of Pernambuco, University of Pernambuco, Camaragibe, Brazil
Correspondence
Antônio Vinicius Holanda Barbosa holanda76@hotmail.com

Received: November 24, 2017

Accepted: January 14,2019

Conflict of Interests: The authors state that there Co no financial and personal conflicts of interest that could have inappropriately influenced their work.

Copyright: @ 2018 Barbosa et al licensee EDIPUCRS.

This work is licensed under a Creative Commons Attribution 4.0 International License. 


\section{INTRODUCTION}

The search for biocompatible dental materials presenting good physical, chemical and mechanical properties is still ongoing. In Endodontics, this search has been intense [1]. Several studies have demonstrated that mineral trioxide aggregate (MTA) shows good physical, chemical, mechanical and biological properties [2-4] and its behavior has been largely investigated in several clinical applications $[6,7]$.

MTA is largely composed of Portland cement (PC) [8] and proves to be the most suitable material for pulpotomy and sealing communications between the pulp cavity and periodontal ligament, favoring the periradicular repair region [9]. The similarity between MTA and PC is shown in their potential for biomineralization [10], for sealing capacity [11] and in the pulp biocompatibility in animal experiments [12]. As these materials exhibit compatibility among their compounds, the possibility of clinical use of PC has been considered as an alternative to MTA [1].

However, PC is still used sparingly due to gaps in the quality of the scientific evidence available regarding the use in humans, especially on their biocompatibility. Therefore, the purpose of this study was to evaluate pulp response (in vivo) of PC and MTA. For the null hypothesis was considered that there is no difference between the biocompatibility of MTA and Portland cement.

\section{METHODS}

This study was approved by the Internal Review Board (IRB) of the University of Pernambuco (Protocol No. 015/08), in accordance with the World Medical Association Declaration of Helsinki. The written information explaining the purpose of the study was signed by each volunteer of this study. This study was conducted in the city of Recife, in Pernambuco, northeastern Brazil.

Forty human third molars scheduled to be extracted for orthodontic reasons were selected from patients ranging from 19 to 31 years old. All teeth were examined clinically and radiographically. The criteria for inclusion in the study were the following: (a) patients who had not been exposed to previous endodontic treatment, (b) absence of caries and periapical lesions, (c) patients who had not been taking any drugs and (d) patients with no periodontal diseases.

The vitality of all teeth was tested with a thermal testing. ENDO-ICE ${ }^{\circledR}$ frozen gas (Coltène /Whaledent Inc, Mahwah, $\mathrm{NJ})$ was applied for 5 seconds on the buccal surface of the teeth scheduled for the pulp therapy as well as on the adjacent teeth. A single calibrated investigator selected and treated the subjects.

Thus, 20 teeth were intended to act as the experimental group, Portland cement (PC), and 20 teeth were intended to act as the control group, Mineral Trioxide Aggregate (MTA).

The method of randomization was performed to maintain a similar distribution of the number of teeth in each group. The teeth selected for the study were then described in a paper that was included in an envelope drawn up for each type of intervention.

The teeth were clinically treated by one examiner. The follow up histologic exams were performed by another calibrated examiner who was blind to the type of treatment. The patients were also blind to the type of treatment.

Under local anesthesia - Mepivacaine 2\% with epinephrine 1:100.000 - (Mepiadre 100 ${ }^{\circledR}$, DFL, Brazil) and with a rubber dam properly positioned, occlusal cavities were prepared with the aid of sterile diamond burs (\# 1015, KG Sorensen, Barueri, São Paulo, Brazil) at high speed under water/spray coolant. Pulp exposure was performed in the center of the pulpal floor with the aid of a round diamond bur under water-cooling (\#1013, $\varphi$ 1.2, KG Sorensen). One bur was used for each cavity. Bleeding was only controlled by abundant irrigation with a sterile saline solution followed by the application of a damp cotton pellet embedded in the saline solution.

In the PC group, the pulps were capped with Portland cement (CPII-F32 ${ }^{\circledR}$, Nassau, PE, BRAZIL). In the MTA group, the pulps were capped with grey MTA Angelus (Angelus $^{\circledR}$, Londrina, Brazil). All materials were mixed at a 3:1 powder - distilled water ratio and placed onto the pulp wound. Light pressure was applied with a wet cotton pellet to secure the material. The cavities were subsequently sealed and restored with a glass ionomer (Vitromolar ${ }^{\mathbb{B}}$, DFL, Brazil).

In order to accomplish the evaluation of the evolution of pulp response by the histologic examination, a total of five teeth from each group were subjected to extraction in intervals of 1, 714 and 21 days after the treatment.

The apical thirds of all roots were sectioned in $5 \mathrm{~mm}$ in order to assist the fixation in a $10 \%$ buffered formalin solution for $72 \mathrm{hrs}$. Afterwards, the teeth were placed in sodium citrate buffered formic acid for demineralization. Tissue blocks were dehydrated and embedded in paraffin. Serial sections were cut at a setting of $5 \mu \mathrm{m}$ in a buccolingual direction and stained with hematoxylin and eosin $(\mathrm{H} / \mathrm{E})$ and Brown \& Hopps (BH). The sections were blindly assessed by a pathologist according to the criteria previously established by Cox et al., [13,14] and Akimoto et al., [15] (Table 1). The variables analyzed inflammatory cell response, soft tissue organization, dentin bridge formation and bacterial staining.

For the data analysis, normal distribution of quantitative data was checked using the Kolmogorov-Smirnov test, with the Mann-Whitney test being applied to compare the quantitative variables between groups. Statistical tests were performed with a margin of error of 5.0\%. Data were stored on an EXCEL spreadsheet and statistics were calculated using the Statistical Package for the Social Sciences (SPSS) version 17 (IBM, Chicago, IL, USA).

On separate occasions, $10 \%$ of the sample was randomly selected to be re-examined for intra-examiner reproducibility. Intra-examiner reproducibility for pulp condition diagnosis was calculated by Cohen's kappa test. The kappa for the intra-examiner agreement was of 0.90 . 
Table 1. Criteria for histopathologic diagnosis.

\begin{tabular}{|c|c|}
\hline Scores & Inflammatory cell response \\
\hline 1 & $\begin{array}{l}\text { None or a few scattered inflammatory cells present in the } \\
\text { pulp beneath the exposure site }\end{array}$ \\
\hline 2 & $\begin{array}{l}\text { Polymorphonuclear leukocytes (acute) or mononuclear } \\
\text { lymphocytes (chronic) in an inflammatory lesion }\end{array}$ \\
\hline 3 & $\begin{array}{l}\text { Severe inflammatory lesion appearing as an abscess or } \\
\text { dense infiltrate involving one third or more of the coronal } \\
\text { pulp }\end{array}$ \\
\hline 4 & Completly necrotic pulp \\
\hline Scores & Soft tissue organization \\
\hline 1 & $\begin{array}{l}\text { Normal or almost normal tissue morphology below the } \\
\text { exposure site and throughout the pulp }\end{array}$ \\
\hline 2 & $\begin{array}{l}\text { Lack of normal tissue morphology below the exposure } \\
\text { site, with deeper pulp tissue appearing normal }\end{array}$ \\
\hline 3 & $\begin{array}{l}\text { Loss of general pulp morphology and cellular organization } \\
\text { below the exposure site }\end{array}$ \\
\hline 4 & Necrosis in the coronal third of the pulp \\
\hline Scores & Dentin bridge formation \\
\hline 1 & $\begin{array}{l}\text { New barrier tissue directly adjacent to some portion of the } \\
\text { restorative material }\end{array}$ \\
\hline 2 & $\begin{array}{l}\text { New dentin bridge some distance from the material } \\
\text { interface }\end{array}$ \\
\hline 3 & $\begin{array}{l}\text { No evidence of any dentin tissue formation in any of the } \\
\text { tissue sections }\end{array}$ \\
\hline Scores & Bacterial staining \\
\hline 1 & Absence of bacterial staining in any section \\
\hline 2 & $\begin{array}{l}\text { Positive bacterial staining reaction along the cavity walls } \\
\text { or within the cut dentin tubules }\end{array}$ \\
\hline 3 & Positive bacterial staining reaction within the dental pulp \\
\hline
\end{tabular}

\section{RESULTS}

The data from the histological examination are summarized in Table 2. Both groups performed well in terms of histological pulp findings. However, based on statistical analysis, MTA demonstrated to have a higher dentin bridge formation capacity than PC at intervals of $14(\mathrm{p}=0.015)$ and 21 days $(\mathrm{p}=0.014)$.

After 21 days, only one case of PC group exhibited dentin bridge formation; however, such bridge was found at some distance from the pulp-PC interface (Figure 1A). A tubular dentin bridge formation was also observed below the exposure area in two tissue sections. (Figure 1B).

However, on all other variables regarding pulp response (inflammatory cell response, soft tissue organization, dentin bridge formation and bacterial staining) no significant statistical difference was found between the MTA and PC groups in all assessment intervals.

\section{DISCUSSION}

The null hypothesis of this study was not supported by the present report. It was observed that MTA and PC pulp cements have statistically different responses. As for the pulp response of human teeth, MTA presented better results regarding the formation of the dentin bridge. But no statistically significant difference was found in all other parameters evaluated (inflammatory cell response, soft tissue organization and staining bacterial), which shows an equivalent biocompatibility for these.

Table 2. Histological and bacterial staining response in exposed human pulp

\begin{tabular}{|c|c|c|c|c|c|c|c|c|c|c|c|c|c|c|c|c|c|c|c|}
\hline \multirow[t]{2}{*}{ Day } & \multirow[t]{2}{*}{ Material } & \multicolumn{4}{|c|}{$\begin{array}{l}\text { Inflammatory } \\
\text { cell response }\end{array}$} & \multirow[t]{2}{*}{$p$ value } & \multicolumn{4}{|c|}{$\begin{array}{c}\text { Soft tissue } \\
\text { organization }\end{array}$} & \multirow[t]{2}{*}{$p$ value } & \multicolumn{3}{|c|}{$\begin{array}{l}\text { Dentin bridge } \\
\text { formation }\end{array}$} & \multirow[t]{2}{*}{$\mathrm{p}$ value } & \multicolumn{3}{|c|}{$\begin{array}{l}\text { Bacterial } \\
\text { staining }\end{array}$} & \multirow[t]{2}{*}{$p$ value } \\
\hline & & 1 & 2 & 3 & 4 & & 1 & 2 & 3 & 4 & & 1 & 2 & 3 & & 1 & 2 & 3 & \\
\hline \multirow[t]{2}{*}{1} & PC & 5 & 0 & 0 & 0 & \multirow{2}{*}{$p>0.05$} & 5 & 0 & 0 & 0 & \multirow{2}{*}{$p=0.317$} & 0 & 0 & 5 & \multirow{2}{*}{$p>0.05$} & 5 & 0 & 0 & \multirow{2}{*}{$p>0.05$} \\
\hline & MTA & 5 & 0 & 0 & 0 & & 4 & 1 & 0 & 0 & & 0 & 0 & 5 & & 5 & 0 & 0 & \\
\hline \multirow[t]{2}{*}{7} & PC & 5 & 0 & 0 & 0 & \multirow{2}{*}{$p>0.05$} & 4 & 0 & 1 & 0 & \multirow{2}{*}{$p=0.317$} & 0 & 0 & 5 & \multirow{2}{*}{$p>0.05$} & 5 & 0 & 0 & \multirow{2}{*}{$p>0.05$} \\
\hline & MTA & 5 & 0 & 0 & 0 & & 5 & 0 & 0 & 0 & & 0 & 0 & 5 & & 5 & 0 & 0 & \\
\hline \multirow[t]{2}{*}{14} & PC & 5 & 0 & 0 & 0 & \multirow{2}{*}{$p>0.05$} & 0 & 4 & 1 & 0 & \multirow{2}{*}{$p=0.093$} & 0 & 1 & 4 & \multirow{2}{*}{$p=0.015$} & 5 & 0 & 0 & \multirow{2}{*}{$p>0.05$} \\
\hline & MTA & 5 & 0 & 0 & 0 & & 2 & 3 & 0 & 0 & & 1 & 4 & 0 & & 5 & 0 & 0 & \\
\hline \multirow[t]{2}{*}{21} & PC & 5 & 0 & 0 & 0 & \multirow{2}{*}{$p>0.05$} & 0 & 5 & 0 & 0 & \multirow{2}{*}{$p>0.05$} & 0 & 1 & 4 & \multirow{2}{*}{$p=0.014$} & 5 & 0 & 0 & \multirow{2}{*}{$p>0.05$} \\
\hline & MTA & 5 & 0 & 0 & 0 & & 0 & 5 & 0 & 0 & & 2 & 3 & 0 & & 5 & 0 & 0 & \\
\hline
\end{tabular}

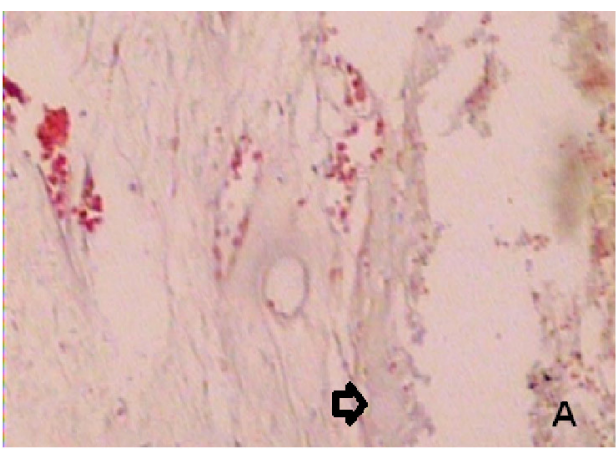

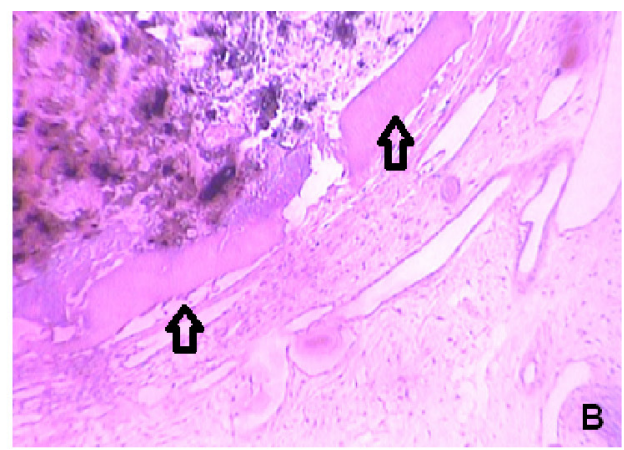

Figure 1. Formation of dentin bridge (black arrows) after 21 days with PC (A) and MTA (B) 
Recent findings of studies where MTA had been compared with Portland cement have shown that both materials seem to be almost identical in relation to the physico-chemical, mechanical and biological properties $[16,17]$ However, it was not confirmed in our study for dentin bridges formation. The MTA showed to be able to form more uniform and continuous bridges just below the pulp-material interface (Figure 1B). The PC formed irregular dentine bridges and some distance from the material interface (Figure 1A).

Although the precise mechanism by which PC induces hard tissue bridge formation is not completely understood, there are hints that the mechanism of initiation of reparative dentinogenesis in capping with PC and MTA cement is somehow similar $[17,18]$. Their ability to support dentin bridge formation may be attributed to their excellent sealing ability. Some authors have reported that both MTA and PC release calcium ions when in contact with tissue fluids, thus promoting an alkaline $\mathrm{pH}$ [17-21].

This Interaction produces calcium silicate hydrate gel and calcium hydrate, which would explain why MTA, PC, and calcium hydroxide cause similar tissue reactions [22]. Despite the fact that both materials performed well in terms of histological pulpal findings, this work could not reject the fact that a faster hard tissue bridge formation occurred when MTA was used. A significant difference was observed between MTA and PC after 14 days. Thus, it seems that MTA takes advantage in producing patterns of healing in a shorter period of time [23].

Takita et al. [24] found that the continuous release of calcium ions by MTA is directly related to the induction of proliferation by human dental pulp cells. According to Faraco and Holland [25], the presence of necrotic tissue nearest to the dentin bridge formation suggests that PC and MTA initially cause necrosis by coagulation in contact with the pulp connective tissue. Such reaction might occur because of the high alkalinity of the products, with a $\mathrm{pH}$ close to 9-10 [19,20]. This pulp response was found in our study in until seven days for both materials.

No significant difference regarding the presence of microorganisms was found among the groups evaluated. This means that the bacteriostatic action of PC and MTA $[19,26]$ was enough to reduce the number of viable bacteria near the pulp exposure. There was also no statistically significant difference $(p<0.05)$ between the cements analyzed for the variables inflammatory cell response and the soft tissue organization for all assessment intervals, which indicates an equivalence in these parameters' biocompatibility.

\section{CONCLUSION}

The evaluation of the pulpal response in human teeth showed that the PC has a biocompatibility equivalent to the MTA, but with a lower capacity to form of dentin bridge. Therefore, MTA should be the material of choice for direct pulp capping.

\section{REFERENCES}

1. Oliveira MG, Xavier CB, Demarco FF, Pinheiro ALB, Costa AT, Pozza DH. Comparative chemical study of MTA and Portland cements. Braz Dent J 2007;18:3-7. https://doi.org/10.1590/S0103-64402007000100002

2. Johnson BR. Considerations in the selection of a root-end filling material. Oral Surg Oral Med Oral Pathol Oral Radiol Endod 1999:87:398-404. https://doi.org/10.1016/S1079-2104(99)70237-4

3. Lee BN, Son HJ, Noh HJ, Koh JT, Chang HS, Hwang IN, et al. Cytotoxicity of newly developed ortho MTA root-end filling materials. J Endod 2012;38:1627-1630. https://doi.org/10.1016/j.joen.2012.09.004

4. Cunha SA, Rached FJ Jr, Alfredo E, León JE, Perez DE. Biocompatibility of sealers used in apical surgery: a histological study in rat subcutaneous tissue. Braz Dent J 2011:22:299-305. https://doi.org/10.1590/S010364402011000400007

5. Silva GF Guerreiro-Tanomaru JM, Sasso-Cerri E, Tanomaru-Filho M, Cerri OS. Histological and histomorphometrical evaluation of furcation perforations filled with MTA, CPM and ZOE. Int Endod J 2011;44:100-10. https://doi.org/10.1111/j.1365-2591.2010.01803.x

6. Al Hiyasat AS, Al Sa'Eed OR, Darmani H. Quality of cellular attachment to various root-end filling materials. J Appl Oral Sci 2012;20:82-8. https:// doi.org/10.1590/S1678-77572012000100015

7. Camilleri $\mathrm{J}$. Characterization of hydration products of mineral trioxide aggregate. Int Endod J 2008;41:408-17. https://doi.org/10.1111/j.13652591.2007.01370.x

8. Natu VP, Dubey N, Loke GCL, et al. Bioactivity, physical and chemical properties of MTA mixed with propylene glycol. Journal of Applied Oral Science 2015:23:405-411. https://doi.org/10.1590/1678-775720150084

9. Hugar SM, Deshpande SD. Comparative investigation of clinical/ radiographical signs of mineral trioxide aggregate and formocreso on pulpotomized primary molars. Contemporary Clinical Dentistry 2010;1:146-151. https://doi.org/10.4103/0976-237X.72779

10. Güven EP, Taşlı PN, Yalvac ME, Sofiev N, Kayahan MB, Sahin F. In vitro comparison of induction capacity and biomineralization ability of mineral trioxide aggregate and a bioceramic root canal sealer. Int Endod J 2013;46:1173-82. https://doi.org/10.1111/iej.12115

11. Espir CG, Guerreiro-Tanomaru JM, Spin-Neto R, Chávez-Andrade GM, Berbert FL, Tanomaru-Filho M. Solubility and bacterial sealing ability of MTA and root-end filling materials. J Appl Oral Sci 2016;24:121-5. https:// doi.org/10.1590/1678-775720150437

12. Scelza MZ, Campos CA, Scelza P, Adeodato CS, Barbosa IB, de Noronha F, Montalli V, Napimoga M, de Araújo VC, Alves GG. Evaluation of Inflammatory Response to Endodontic Sealers in a Bone Defect Animal Model. J Contemp Dent Pract 2016;17:536-41.

13. Cox CF, Keall CL, Keall HJ, Ostro E, Bergenholtz G. Biocompatibility of surface-sealed dental materials against exposed pulps. J Prosthet Dent 1987;57:1-8. https://doi.org/10.1016/0022-3913(87)90104-1

14. Cox CF, Sübay RK, Suzuki S, Suzuki SH, Ostro E. Biocompatibility of various dental materials: pulp healing with a surface seal. Int J Periodontics Restorative Dent 1996;16:240-51.

15. Akimoto N, Momoi Y, Kohno A, Suzuki S, Otsuki M, Suzuki S, Cox CF. Biocompatibility of Clearfil Liner Bond 2 and Clearfil AP-X system on nonexposed and exposed primate teeth. Quintessence Int 1998;29: 177-88.

16. Saidon J, He J, Zhu Q, Safavi K, Spångberg LS. Cell and tissue reactions to mineral trioxide aggregate and Portland cement. Oral Surg Oral Med Oral Pathol Oral Radiol Endod 2003;95:483-9. https://doi.org/10.1067/ moe.2003.20

17. Menezes R, Bramante CM, Letra A, Carvalho VG, Garcia RB. Histologic evaluation of pulpotomies in dog using two types of mineral trioxide aggregate and regular and white Portland cements as wound dressings. Oral Surg Oral Med Oral Pathol Oral Radiol Endod 2004;98:376-9. https:// doi.org/10.1016/j.tripleo.2004.03.008

18. Holland R, de Souza V Murata SS, Nery MJ, Bernabé PF Otoboni Filho JA, Dezan Júnior E. Healing process of dog dental pulp after pulpotomy and pulp covering with mineral trioxide aggregate or Portland cement. Braz Dent J 2001;12:109-13.

19. Camilleri J, Montesin FE, Di Silvio L, Pitt Ford TR. The chemical constitution and biocompatibility of accelerated Portland cement for endodontic use. Int Endod J 2005;38:834-42. https://doi.org/10.1111/j.13652591.2005.01028.x

20. Sarkar NK, Caicedo R, Ritwik P, Moiseyeva R, Kawashimal. Physicochemical basis of the biologic properties of mineral trioxide aggregate. J Endod 2005;31:97-100. https://doi.org/10.1097/01.DON.0000133155.04468.41

21. Gonçalves JL, Viapiana R, Miranda CE, Borges AH, Cruz Filho AM Evaluation of physico-chemical properties of Portland cements and MTA. Braz Oral Res 2010;24:277-83. https://doi.org/10.1590/S180683242010000300004 
22. Accorinte ML, Loguercio AD, Reis A, Carneiro E, Grande RH, Murata SS, Holland R. Response of human dental pulp capped with MTA and calcium hydroxide powder. Oper Dent 2008;33:488-95. https://doi.org/10.2341/ 07-143

23. Ford TR, Torabinejad M, Abedi HR, Bakland LK, Kariyawasam SP. Using mineral trioxide aggregate as a pulp-capping material. J Am Dent Assoc 1996;127:1491-4. https://doi.org/10.14219/jada.archive.1996.0058

24. Takita T, Hayashi M, Takeichi O, Ogiso B, Suzuki N, Otsuka K, Ito K. Effect of mineral trioxide aggregate on proliferation of cultured human denta pulp cells. Int Endod J 2006;39:415-22. https://doi.org/10.1111/i.13652591.2006.01097.x

25. Faraco IM Jr. Holland R. Response of the pulp of dogs to capping with mineral trioxide aggregate or a calcium hydroxide cement. Dent Traumatol 2001:17:163-6. https://doi.org/10.1034/j.1600-9657.2001.170405.x

26. Vivan RR, Zapata RO, Zeferino MA, Bramante CM, Bernardineli N, Garcia $\mathrm{RB}$, et al. Evaluation of the physical and chemical properties of two commercial and three experimental root-end filling materials. Oral Surg Oral Med Oral Pathol Oral Radiol Endod 2010;110:250-6. https://doi. org/10.1016/j.tripleo.2010.04.021

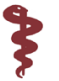

